\title{
HIDUP SEBAGAI ORANG ASING BERDASARKAN KITAB RUT
}

\author{
Sia Kok Sin
}

\begin{abstract}
Abstraksi: Hidup sebagai orang asing atau pendatang merupakan masalah yang umum dan kompleks termasuk dalam dunia Perjanjian Lama. Kitab Rut merupakan salah satu kitab Perjanjian Lama yang mengungkapkan suka dan duka kehidupan sebagai orang asing. Baik ketika keluarga Elimelekh hidup sebagai orang asing di Moab dan kemudian Rut yang meninggalkan Moab untuk mengikuti Naomi kembali ke tanah Yehuda. Rut, seorang perempuan Moab yang bertahan hidup melalui hukum sisa panen, dan dapat mempunyai suami (Boas) melalui penerapan hukum penebusan oleh kaum keluarga dan pernikahan ipar, akhirnya menjadi leluhur dari raja Daud.
\end{abstract}

Kata-kata Kunci: Moab, Yehuda, Orang Asing, Rut dan Boas

\begin{abstract}
To live as a stranger is common and complex problem in human history, including the world of the Old Testament. The book of Ruth is one of the books that told the story of living as a stranger. Elimelech and his family lived as strangers in Moab, and then Ruth, who joined her mother in law, lived as a stranger at Judah, her mother in law's homeland. Ruth, the Moabite woman survived to live as a stranger because of the law of gleaning and had a husband (Boaz) because of the law of kinsman redeemer and leviarate marriage and finally she became an ancestress of the king David.
\end{abstract}

Keywords: Moab, Judah, Stranger, Ruth and Boaz 
Dewasa ini masalah imigran menjadi masalah yang kembali mencuat, oleh karena semakin banyak orang yang meninggalkan negaranya pergi ke negera lain untuk mendapatkan kehidupan yang lebih baik. ${ }^{1}$ Negara-negara yang menjadi tujuan para pendatang ini juga sedang mengalami gejolak oleh karena mereka merasa terganggu dengan kehadiran para pendatang ini. ${ }^{2}$ Kehadiran pendatang atau orang asing di suatu tempat biasanya membawa dinamika dalam kehidupan komunitas tersebut. Bahkan kehadiran etnis Tionghoa yang telah lama di Indonesia pun tidak terlepas dari gejolak pasang surut. ${ }^{3}$

Salah satu bagian Kitab Suci yang sering diselidiki dan diaplikasikan dalam konteks problematika kaum pendatang atau orang asing adalah kitab Rut. ${ }^{4}$ Kitab Rut mengawali kisahnya dengan kepindahan keluarga Elimelekh dari Betlehem-Yehuda ke tanah Moab oleh karena kelaparan. Keluarga Elimelekh hidup sebagai pendatang di tanah Moab. Kedua anak lelakinya menikah dengan perempuan Moab yang bernama Orpa dan Rut. Kisah tersebut berlanjut dengan keputusan Naomi untuk kembali ke tanah

\footnotetext{
${ }^{1}$ James K. Hoffmeier, The Immigration Crisis. Immigrants, Aliens, and the Bible (Wheaton: Crossway Books, 2009), 19-20.

${ }^{2}$ Anthony Rees memaparkan kebijakan politis Australia yang semakin menolak kehadiran para pendatang yang meminta suaka. Anthony Rees, "The Boaz Solution: Reading Ruth in Light of Australian Asylum Seeker Discourse”, in Reading Ruth in Asia (Atlanta: SBL Press, 2015), 100-4. Begitu juga pemerintahan Amerika Serikat di bawah kepemimpinan Presiden Donald J. Trump.

${ }^{3}$ Penulis sendiri menulis sebuah buku tentang dinamika keberadaan etnis Tionghoa di Indonesia. Sia Kok Sin, Ketika Semakin Terbuka. Dinamika Keberadaan Etnis Tionghoa di Indonesia dan Implikasinya bagi Pelayanan Gereja Etnis Tionghoa, Cet. IV (Malang: Media Nusa Creative, 2015).

${ }^{4}$ Hoffmeier, The Immigration Crisis, 103-107. Beberapa artikel dalam Reading Ruth in Asia menyelidiki kitab Rut dalam pengaplikasian masalah kaum pendatang atau orang asing. Jione Havea and Peter H. W. Lau, Reading Ruth in Asia (Atlanta: SBL Press, 2015). M. Daniel Carroll R., "Once a Stranger, Always a Stranger? Immigration, Assimilation, and the Book of Ruth", in International Bulletin of Missionary Research, Vol. 39, No. 4, Oktober 2015, 185-8.
} 
Yehuda setelah kematian kedua anak lelakinya. Naomi kembali ke tanah airnya bersama dengan Rut, menantunya yang bersikukuh untuk mendampinginya. Selanjutnya, kitab Rut berpusatkan pada kisah Rut, seorang perempuan Moab yang memilih untuk meninggalkan tanah airnya dan mengikuti mertuanya untuk hidup sebagai orang asing di Yehuda, tanah air mertuanya. James K. Hoffmeier mengungkapkan bahwa kisah dalam kitab Rut indah dan menyentuh, serta mengungkapkan bagaimana Israel hidup sebagai orang asing di Moab dan bagaimana seorang wanita Moab diperlakukan oleh bangsa Israel. ${ }^{5}$ Kitab ini secara luar biasa menceritakan perjuangan Rut, seorang perempuan Moab yang pada akhirnya menjadi bagian dari silsilah dari raja Daud, raja terbesar bangsa Israel.

Edward Allen Jones III secara ringkas mengungkapkan pelbagai pendapat para ahli yang menempatkan kitab Rut sebagai karya sastra antara masa Kerajaan, masa Pembuangan ataupun masa Pemulihan (Bait Suci Kedua). ${ }^{6}$ Kitab ini dianggap sebagai pembelaan sosio-politis terhadap hak dinasti Daud atas Israel atau karya "perlawanan" (counter) terhadap kecenderungan eklusivisme pada masa Pemulihan atau sekadar teks yang mengajarkan pembaca untuk hidup setia dan murah hati serta percaya kepada karya pemeliharaan Allah. ${ }^{7}$

Pengkategorian kitab Rut sebagai suatu karya sastra protes ( $a$ protest literature) yang menegaskan adanya keberadaan dan peran positif orang asing di Israel di tengah dorongan untuk memisahkan diri dari orang asing pada zaman Nehemia dan Ezra (abad kelima

\footnotetext{
${ }^{5}$ Hoffmeier, The Immigration Crisis, 106.

${ }^{6}$ Edward Allen Jones III, Reading Ruth in the Restoration Period. A Call for Inclusion. Library of Hebrew Bible/Old Testament Studies, 604 (New York: Bloomsbury T \& T Clark, 2016), 4.

${ }^{7}$ Jones III, Reading Ruth in the Restoration Period, 4-9.
} 
sebelum Masehi) ${ }^{8}$ sangat menarik untuk memberikan konteks kisah tentang "keramahan" (hospitality) terhadap orang asing, baik yang dialami oleh keluarga Elimelekh di Moab atau pun Rut di tanah Yehuda.

\section{Keasingan Keluarga Elimelek di Tanah Moab}

Rut 1 mengisahkan ada sebuah keluarga dari BetlehemYehuda yang terpaksa meninggalkan tanah airnya menuju ke tanah Moab oleh karena bencana kelaparan. Keluarga ini terdiri dari Elimelekh, Naomi dan kedua anak lelakinya yang bernama Mahlon dan Kilyon. Roop menyatakan bahwa kepindahan keluarga Elimelekh ini merupakan suatu migrasi yang memalukan, karena demi menghindari kelaparan mereka pindah dari Betlehem (yang artinya "rumah roti") menuju ke Moab, yang mempunyai konotasi negatif dalam kehidupan bangsa Israel. ${ }^{9}$

Istilah (gwr) yang dapat mempunyai arti hidup sebagai pendatang/orang asing, digunakan dalam Rut 1:1 menunjukkan bahwa keluarga ini tidak pindah secara permanen di Moab. Masa tinggal mereka di Moab dapat saja lama, tetapi mereka tidak pernah berpikir untuk tinggal secara permanen. Tidak jelas sesudah beberapa lama mereka tinggal di Moab, diungkapkan bahwa Elimelekh meninggal.

Setelah Elimelekh meninggal, kedua anak lelakinya menikah dengan perempuan Moab yang bernama Orpa dan Rut. Robert D. Holmstedt mengungkapkan bahwa penggunaan istilah "mengambil istri” ( נשא אשח

\footnotetext{
${ }^{8}$ Eugene F. Roop, Ruth, Jonah, Esther. Believers Church Bible Commentary (Scotdale: Herald Press, 2002), 20; Peter H. W. Lau, "Another Postcolonial Reading of the Book of Ruth", in Reading Ruth in Asia (Atlanta: SBL Press, 2015), 29-33; Jones III, Reading Ruth in the Restoration Period, 9.

${ }^{9}$ Roop, Ruth, Jonah, Esther, 29.
} 
yang tanpa adanya mas kawin (mahar) oleh karena berkaitan dengan status yang rendah dan miskin. ${ }^{10}$ Mahlon dan Kilyon adalah pendatang yang miskin, sehingga tidak dapat membayar mas kawin (mahar) dalam pernikahan mereka. Orpa dan Rut bersedia diambil istri oleh mereka, kemungkinan juga menunjukkan status mereka yang rendah dan miskin. Menikah dengan perempuan "lokal" umumnya biasanya bukanlah pilihan utama seorang pendatang atau asing, tetapi hal ini terjadi oleh karena situasi dan kebutuhan yang terelakkan. Naomi pun harus menerima kedua menantu perempuannya yang merupakan perempuan Moab. Kehidupan pernikahan kedua anak lelakinya hanya berlangsung sekitar sepuluh tahun, oleh karena mereka meninggal (Rut 1:4-5). Naomi merasa bahwa ia tinggal sendirian dan kehilangan suami dan kedua anak lelakinya. Naomi kini hidup dalam situasi bahaya yang serius, karena ia seorang janda, tanpa keluarga dan tinggal di negeri asing. 11

Kisah ini berlanjut dengan keputusan Naomi untuk kembali ke tanah Yehuda, oleh karena ia mendengar bahwa Allah telah melepaskan bangsanya dari bencana kelaparan (Rut 1:6). Tidak ada sesuatu yang dapat diharapkan oleh Naomi di tanah Moab. Impiannya untuk meraih kehidupan lebih baik di negeri asing tidaklah tercapai. Ia tinggal "sendiri". Tidak ada yang perlu dipertahankan di Moab. Ia memutuskan untuk kembali ke tanah airnya, khususnya setelah mendengar bahwa kondisi di tanah airnya lebih baik. Tanpa adanya lelaki dalam keluarga ini, status Naomi dan kedua menantunya di Moab menjadi semakin tidak jelas. Kembali ke tanah airnya bagi Naomi masih menyisakan

\footnotetext{
${ }^{10}$ Istilah yang lebih umum "mengambil istri" adalah לקח אשה (lqh ’šh). Robert D. Holmstedt, Ruth. A Handbook on The Hebrew Text (Waco, Texas: Baylor University Press, 2010), 33.

${ }^{11}$ Roop, Ruth, Jonah, Esther, 30.
} 
kemungkinan adanya kerabatnya yang mempunyai tanggung jawab untuk menolongnya. ${ }^{12}$

Dalam perjalanan kembali, Naomi mendesak kedua menantu perempuannya untuk tidak ikut bersamanya, tetapi kembali kepada orang tua mereka. Orpa mau kembali ke rumah keluarganya, sedangkan Rut bersikeras untuk mendampingi Naomi ke Betlehem.

Kisah keluarga Elimelekh yang hidup sebagai orang asing di Moab memang tidak banyak diceritakan, namun dapat dikatakan bahwa mereka mengalami "keramahan" orang Moab. Walau secara umum hubungan antara Israel dan Moab digambarkan selalu bermusuhan, ${ }^{13}$ namun tidak ada catatan tentang perlakuan buruk orang Moab terhadap keluarga Elimelekh ini. Bahkan kedua anak lelakinya menikahi perempuan Moab.

Memang pengalaman keluarga yang berpindah ke tanah asing ini, yaitu Moab bukanlah kisah yang berakhir dengan baik. Mereka berpindah untuk menghindari kelaparan, tetapi pada akhirnya mengalami kematian. Ketika Naomi mengungsi ke Moab, ia bersama keluarganya, tetapi ia kembali ke tanah airnya, ia merasa sebagai seorang diri. Pengalaman hidup sebagai pendatang baginya bukanlah pengalaman yang membawa kepada peningkatan kualitas hidup, tetapi justru membawa kepada pengalaman yang pahit. (bdk. Rut 1:20-21).

Joshua A. Berman mengutip Targum dan menafsirkan secara teologis perihal kematian Elimelekh dan kedua anak lelakinya merupakan hukuman Allah. Elimelekh dihukum oleh karena

\footnotetext{
${ }^{12}$ Agnethe Siquans, "Foreignness and Poverty in the Book of Ruth: A Legal Way for a Poor Foreign Woman to Be Integrated into Israel", in Journal of Biblical Literature, 128, no. 3 (2009): 445.

${ }^{13}$ Jones III, Reading Ruth in the Restoration Period, 18.
} 
membawa keluarganya ke tanah yang najis, sedangkan kedua Mahlon dan Kilyon dihukum oleh karena mereka menikah dengan perempuan asing. ${ }^{14}$ Secara sosiologis kisah kematian Elimelekh dan kedua anak lelakinya dapat merupakan kisah yang menyedihkan pengalaman hidup seseorang yang berpindah dari tanah airnya ke negara asing. Berpindah untuk menghindari kelaparan, tetapi pada akhirnya mengalami kematian. Kisah seperti ini juga menjadi pengalaman hidup banyak para pendatang. Berpindah dari tanah air menuju ke tanah asing tidaklah menjadi jaminan bagi seseorang atau suatu keluarga untuk dapat menikmati kehidupan yang lebih baik. Memang ada kisah-kisah sukses, tetapi lebih banyak kisah yang menyedihkan. Hidup sebagai orang asing merupakan suatu pilihan dan keputusan yang harus dipertimbangkan secara matang.

\section{Keasingan Rut di Tanah Yehuda Rut Menjadi Orang Asing}

Naomi memutuskan untuk kembali ke tanah airnya, maka ia menasihati dan mendesak kedua menantunya untuk tetap tinggal di Moab dan tidak mengikutinya ke tanah Yehuda. Orpa memutuskan tetap tinggal di Moab dan kembali kepada orang tuanya, tetapi Rut memilih untuk tetap bersama dengan Naomi.

Rut diperhadapkan untuk memilih antara tinggal di tanah airnya (Moab) atau ikut dengan mertuanya ke tanah asing (Yehuda). Tinggal di tanah airnya (Moab) bukanlah sesuatu yang mudah oleh karena stigma yang melekat dalam dirinya sebagai janda orang asing dan tanpa anak. ${ }^{15}$ Bagi Rut tidaklah mudah untuk

\footnotetext{
${ }^{14}$ Joshua A. Berman, "Ancient Hermeneutics and the Legal Structure of the book of Ruth", in Zeitschrift für die alltestamentliche Wissenschaft, 119, no 1, 2007: 29.

${ }^{15}$ M. Daniel Carroll R., “Once a Stranger, Always a Stranger? Immigration, Assimilation, and the Book of Ruth", in International Bulletin of Missionary Research, Vol. 39, No. 4, Oktober 2015: 186.
} 
menikah lagi atau melanjutkan kehidupannya di tanah airnya. Ia memutuskan dan memilih untuk ikut mertuanya, sehingga memulai fase baru dalam hidupnya sebagai "orang asing”. Roop menilai bahwa tindakan Rut untuk mengikuti Naomi merupakan sikap keras kepala dan ketidaktaatan kepada mertuanya yang dapat saja menyebabkan mertuanya saat itu "marah dalam kesunyiannya", oleh karena Rut hanya menambah beban bagi mertuanya. ${ }^{16}$ Di sisi lain tindakan ini dapat dipandang sebagai tindakan loyalitasnya kepada mertuanya. Tindakan ini dapat juga dilihat sebagai suatu keberanian untuk menghadapi suatu pengalaman yang baru. Salah satu karakteristik seorang yang berani hidup sebagai orang asing adalah sikap berani. Berani menghadapi situasi baru dengan pelbagai tantangan yang tak terduga. Ketika di tanah Moab, Rut bukanlah orang asing atau pendatang, tetapi ketika di Betlehem ia adalah orang asing atau pendatang. Ia adalah seorang wanita Moab

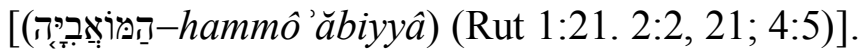

\section{Rut Hidup sebagai Orang Asing}

Rut 1:16-17 menyatakan tekad atau bahkan sumpah Rut kepada Naomi bahwa ia sungguh ingin bersama dengan mertuanya di tanah asal mertuanya itu. "Bangsamulah bangsaku dan Allahmulah Allahku" merupakan tekad Rut untuk mau melepaskan pelbagai latar belakangnya dan "memeluk" latar belakang mertuanya. Andrew J. Niggemann mengungkapkan: "Ruth is the quintessential case study of the foreigner in ancient Israel intent on integration" (Rut adalah studi kasus dari keinginan berintegrasi orang asing dalam Israel kuno). ${ }^{17}$ Sin-lung Tong menafsirkan tekad atau sumpah Rut ini sebagai suatu sikap tunduk seorang yang

\footnotetext{
${ }^{16}$ Roop, Ruth, Jonah, Esther, 38.

${ }^{17}$ Andrew J. Niggemann, "Matriarch of Israel or Misnomer? Israelite SelfIdentification in Ancient Israelite Law Code and the Implications for Ruth", in Journal for the Study of the Old Testament, Vol. 41.3 (2017): 358.
} 
bermigrasi kepada komunitas di mana ia hidup sebagai orang asing. ${ }^{18}$ Sikap inilah yang merupakan sikap yang menyebab Rut dapat ataupun "sukses" hidup sebagai orang asing.

M. Daniel Carroll R. mengungkapkan kehidupan di tanah yang baru (asing) sangatlah kompleks dan banyak tantangan, yang mana dibutuhkan kemampuan yang memadai dari seseorang untuk dapat bertahan dan berhasil. ${ }^{19}$ Rut adalah wanita Moab dan seorang janda, serta tidak mempunyai dukungan dari pihak keluarganya. Ia hanya ditemani oleh Naomi, mertuanya yang hanya mempunyai dukungan dari keluarga jauh dari mendiang suaminya. Dengan kondisi seperti ini hidup sebagai orang asing bukanlah sesuatu yang mudah untuk Rut.

Carroll R. juga menyatakan bahwa salah satu karakter yang dibutuhkan untuk dapat hidup sebagai orang asing adalah proaktif. ${ }^{20}$ Rut 2 mengawali kisahnya dengan permintaan izin Rut kepada Naomi untuk pergi memungut sisa-sisa panen (Rut 2:2-3). Carroll R. menyatakan bahwa tindakan Rut ini mengindikasikan bahwa Rut mengetahui adanya hukum sisa panen (gleaning laws). ${ }^{21}$ Hukum sisa panen (gleaning laws) adalah peraturan yang mengizinkan orang miskin, asing, anak yatim, dan janda untuk memungut sisa panen yang memang sengaja ditinggalkan dalam proses pemanenan hasil (Imamat 19:10; 23:22; Ulangan 24:19-22). Rut harus proaktif untuk dapat bertahan dan hidup di negeri asing.

\footnotetext{
18 Sin-lung Tong, “The Key to Successful Migration? Rereading Ruth's Confession (1:16-17) Through the Lens of Bhabha's Minicry", in Reading Ruth in Asia (Atlanta: SBL Press, 2015), 41-42.

${ }^{19}$ Carroll R., “Once a Stranger, Always a Stranger?”, 185-6.

${ }^{20}$ Carroll R., “Once a Stranger, Always a Stranger?”, 186.

${ }^{21}$ Carroll R., “Once a Stranger, Always a Stranger?”, 186.
} 
Rut 2:5-7 menceritakan tentang pertanyaan Boas dan jawaban para pekerjanya tentang siapakah Rut itu. Ketika Boas bertanya tentang siapakah Rut itu, para pekerja memberikan informasi tentang Rut, seorang perempuan Moab yang kembali bersama Naomi. Mereka juga mengetahui kerja keras Rut dalam memungut sisa panen. Salah satu etos yang sering menandai orang yang hidup sebagai orang asing atau imigran adalah kerja keras.

Hal lain yang dilakukan Rut untuk dapat hidup sebagai orang asing adalah sikap merendahkan diri. Ia menggunakan istilah נָכְריוּיה (nokriyyâ) bagi dirinya ketika ia berjumpa dengan Boas pemilik ladang tempat ia memungut sisa panen (Rut. 2:10). Istilah נָכִרִיוּה (nokriyyâ) merupakan istilah untuk orang asing yang mempunyai konotasi tidak terlalu positif. Istilah ג גרe (gerr) merupakan sebutan orang asing yang lebih dapat diterima oleh komunitas "pribumi". ${ }^{22}$ Dalam disertasinya penulis melakukan penyelidikan terhadap 4 istilah "orang asing” (גָ-gêr, digunakan dalam Perjanjian Lama dan menyimpulkan bahwa:

Dalam kaitan interaksi antara warga pribumi atau penduduk asli dan warga atau orang asing yang diungkapkan dalam Perjanjian Lama, secara umum גֵ dikenakan kepada individu atau kelompok yang "keasingannya" paling kurang dan תוֹשָָׁ merupakan individu atau kelompok yang "lebih

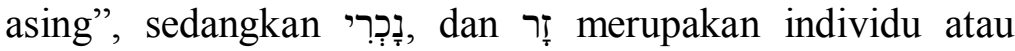
kelompok yang "sangat asing" dan umumnya mempunyai konotasi yang negatif dan berbahaya dalam kehidupan masyarakat Israel. ${ }^{23}$

${ }^{22}$ Carroll R., "Once a Stranger, Always a Stranger?”, 186.

${ }^{23}$ Sia Kok Sin, Keasingan Israel dan Non-Israel dalam Kitab Ulangan serta Etnis Tionghoa di Indonesia, Disertasi, The South East Asia Graduate School of Theology (SEAGST), Yogyakarta, 2008, 45-46. Penyelidikan lebih rinci dapat dilihat dalam bab I "ISTILAH-ISTILAH BERKAITAN DENGAN ORANG ASING DALAM PERJANJIAN LAMA”, 16-46. 
גֵ (gēr) biasanya telah dianggap sebagai bagian dari komunitas suatu tempat, walau tetap ada garis pemisah atau pembeda dengan penduduk asli. ${ }^{24}$ Bangsa Israel diperintahkan untuk menolong atau membantu kelompok masyarakat ini. ${ }^{25}$ Sedangkan נָכְרִ (nokrî) masih dianggap sebagai kelompok yang lebih asing dan kadang mempunyai konotasi berbahaya bagi komunitas dan bangsa Israel tidak mempunyai kewajiban untuk membantu atau menolong kelompok ini. ${ }^{26}$

Rut tidak menekankan statusnya sebagai menantu Naomi, yang sebenarnya dapat dikategorikan sebagai גֵר (gēr), tetapi ia

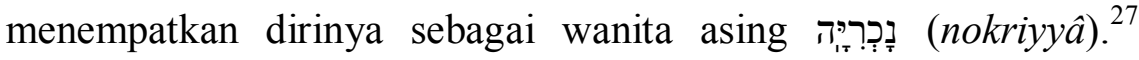
Carroll R. menyatakan bahwa Rut mempunyai beberapa strategi untuk memenangkan simpatik, seperti penggunaan istilah נָכִריוּיָ (nokriyyâ) dan istilah "tuan" yang dikenakan kepada Boas dan istilah "hamba" untuk dirinya. ${ }^{28}$ Sikap merendahkan diri ini penting bagi seorang yang hidup sebagai orang asing. Upaya memperjuangkan status untuk lebih diakui dalam suatu komunitas justru sering mendatangkan ketidaksukaan komunitas "pribumi" kepada kelompok pendatang atau orang asing.

Keberhasilan Rut untuk hidup sebagai asing tidak dapat dilepaskan dari sikap Boas yang baik. ${ }^{29}$ Boas adalah pribadi yang berkuasa dan mempunyai kemampuan untuk melindungi dan mememuhi kebutuhan Rut. ${ }^{30}$ Boas, seorang kaya raya ( אִיש

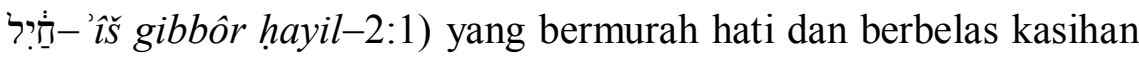

\footnotetext{
${ }^{24}$ Sia, Keasingan Israel dan Non-Israel, 43.

${ }^{25}$ Sia, Keasingan Israel dan Non-Israel, 43.

${ }^{26} \mathrm{Sia}$, Keasingan Israel dan Non-Israel, 30-32.

${ }^{27}$ Hoffmeier, The Immigration Crisis, 105.

${ }^{28}$ Carroll R., “Once a Stranger, Always a Stranger?”, 186.

${ }^{29}$ Tong, "The Key to Successful Migration?, 35.

${ }^{30}$ Anthony Rees, "The Boaz Solution: Reading Ruth in Light of Australian Asylum Seeker Discourse", in Reading Ruth in Asia (Atlanta: SBL Press, 2015), 108.
} 
untuk mengizinkan Rut, seorang asing untuk memungut sisa panen dengan leluasa di ladang miliknya (2:5-10). Ia juga yang berjuang keras agar Rut dapat ditebus dan menjadi istrinya (4:1-13). Melalui penyelidikan para karakter dalam kitab Rut, Jones III menyatakan bahwa Boas merupakan karakter yang menerima Rut sepenuhnya melalui penyediaan bantuan serta keinginan menebus dan menikahinya. $^{31}$ Dalam kaitan dengan hal ini Peter H. W. Lau menyatakan bahwa tindakan Boas terhadap Rut merupakan perluasan penerapan hukum dan dilandasi oleh prinsip moral yang melatarbelakangi hukum serta merupakan penerapan hukum dalam kaitan prinsip hesed. ${ }^{32}$ Sikap Boas yang melebihi hukum dan peraturan Israel untuk menolong dan melindungi orang asing ( di komunitas Israel. ${ }^{33}$ Tanpa uluran tangan Boas dapat dikatakan bahwa Rut akan sulit hidup sebagai orang asing, apalagi dapat berhasil.

\section{Sekali Orang Asing, Tetap Orang Asing}

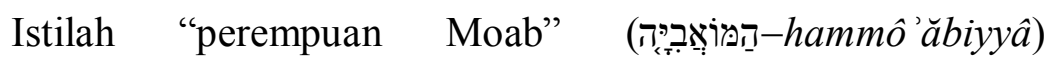
dikenakan pada Rut oleh narator kitab Rut (Rut 1:4, 22; 2:2, 21), para pekerja Boas (Rut 2:6) dan juga oleh Boas (Rut 4:5, 10). Kitab Rut tidaklah menghapus "keasingan" Rut, walau tampak pelbagai hal luar biasa dalam diri Rut atau bahkan peran sertanya dalam kehidupan bangsa Israel. Rut mempunyai kehidupan yang luar biasa. Boas mengakui kesetiaan Rut kepada keluarga Naomi, sehingga ia rela menginggalkan orang tua, keluarga dan bangsanya sendiri (Rut 2:11). Dalam Rut 3:11 ia disebut sebagai perempuan

\footnotetext{
31 Jones III, Reading Ruth in the Restoration Period, 59.

${ }^{32}$ Lau, "Another Postcolonial Reading of the Book of Ruth", in Reading, 20.

${ }^{33}$ Tong, "The Key to Successful Migration?", 42.
} 


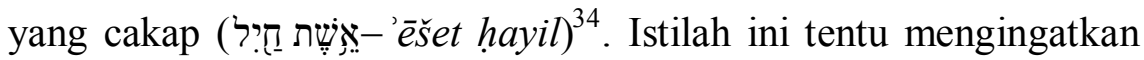
penggunaannya dalam Amsal 31:10 yang diterjemahkan sebagai “isteri yang cakap". Bahkan para perempuan Betlehem mengakui kasih Rut kepada Naomi, mertuanya dan juga menyebutnya lebih berharga dari tujuh anak laki-laki (Rut 4:15). Oleh karena pernikahan Rut dengan Boas, maka mengalirlah silsilah keturunan yang pada akhirnya menunjuk kepada Daud, raja Israel yang terbesar (Rut 4:17-22).

Hal tentang pembelian dan penebusan warisan Elimelekh serta terkaitnya penebusan Rut seringkali dikaitkan dengan hukum atau peraturan tentang pernikahan ipar (levirate marriage) dalam Ulangan 25 dan penebusan oleh kaum keluarga (kinsmen redeemer) dalam Imamat 25. ${ }^{35}$ Memang Brad Embry menafsirkan hal ini tidak hanya sebagai kebiasaan sosial (social custom) dari bangsa Israel, tetapi juga harus dipahami dalam aspek teologis, yaitu Allah sebagai aktor utama dalam kaitan dengan "penebusan dan pembelian" Israel (redemption-acquisition), ${ }^{36}$ namun dalam kaitan dengan pembahasan kehidupn Rut sebagai orang asing, aspek sosial yang lebih diperhatikan dalam artikel ini. Hukum atau peraturan tentang pernikahan ipar (levirate marriage) dalam Ulangan 25 dan penebusan oleh kaum keluarga (kinsmen redeemer)

\footnotetext{
${ }^{34}$ Terjemahan LAI adalah perempuan baik-baik. Terjemahan ini kurang mengungkapkan nuansa istilah bahasa Ibraninya, yang sering dikaitkan dengan istri atau perempuan yang cakap dalam Amsal 31:10-31.

${ }^{35}$ Brad Embry, "Redemption-Acquisition": The Marriage of Ruth as a Theological Commentary on Yahweh and Yahweh's People", in Journal of Theological Interpretation, 7.2 (2013): 258.

${ }^{36}$ Embry, "Redemption-Acquisition", 257-73. Seluruh artikel ini memberikan argumentasi tentang makna teologis lebih dari kebiasaan sosial dari pernikahan Rut. Dalam artikel yang lain Embry mencoba mengaitkan pernikahan Rut dengan kasus anak-anak perempuan Zelafehad yang datang kepada Musa untuk menyelesaikan masalah mereka tentang tanah warisan oleh karena mereka tidak mempunyai saudara laki-laki yang dapat bertindak sebagai ahli waris (Bilangan 27 dan 36). Brad Embry, "Legalities in the Book of Ruth: A Renewed Look", in Journal for the Study of the Old Testament, Vol. 41.1 (2016): 31-44.
} 
dalam Imamat 25 sebenarnya dikenakan kepada bangsa Israel dan bukannya kepada orang asing, sekalipun $(g \bar{e} r) .{ }^{37}$ Pengenaan hukum atau peraturan pernikahan ipar (levirate marriage) ini sebenarnya lebih berkaitan dengan kepentingan kelanjutan silsilah Elimelekh dan bukan terutama untuk kesejahteraan Rut. Embry menyatkan bahwa kelahiran Obed lebih mempunyai manfaat atau keuntungan bagi Naomi dan bukannya Rut. ${ }^{38}$ Kelahiran Obed oleh penulis kitab Rut lebih dikaitkan dengan Naomi daripada Rut. (bdk. Rut 4:16-17). Dalam kaitan dengan hal ini, penulis berpendapat bahwa penerapan hukum ini tidak menunjuk bahwa Rut telah diakui saudara sebangsa dalam konteks kehidupan Israel. Penerapan hukum ini diperlukan demi keberlangsungan keturunan Elimelekh dan bukan menunjuk kepada status Rut yang telah diterima menjadi bagian dari Israel. Rut tetaplah sebagai pendatang atau orang asing. Sedangkan dalam kaitan dengan penggenaan hukum atau peraturan penebusan oleh kaum keluarga (kinsmen redeemer) nampaknya tidak banyak dikaitkan dengan kepemilikan tanah warisan oleh Rut, oleh karena penulis kitab Rut sama sekali tidak menyinggung hal ini. Penebusan ini lebih terkait dengan kepentingan Boas yang ingin menjadikan Rut sebagai istrinya. Penulis berpendapat bahwa penerapan hukum atau peraturan tentang pernikahan ipar (levirate marriage) dalam Ulangan 25 dan penebusan oleh kaum keluarga (kinsmen redeemer) dalam Imamat 25 ini lebih berkaitkan dengan kepentingan Boas dan Naomi daripada Rut. Oleh karena itu, penulis berpendapat bahwa walaupun Rut mempunyai kehidupan yang luar biasa di Betlehem dan peran penting dalam sejarah bangsa Israel, ia tetaplah perempuan Moab. Dalam kaitan dengan hal ini Carroll R. menyatakan "Ruth is among them and appreciated by them, but still not of them". ${ }^{39}$ Jones III menyatakan bahwa terlepas dari tindakan

\footnotetext{
${ }^{37}$ Bdk. Embry, "Redemption-Acquisition", 259-62.

${ }^{38}$ Embry, "Legalities in the Book of Ruth", 35.

${ }^{39}$ Carroll R., "Once a Stranger, Always a Stranger?”, 187.
} 
kesetiaan dan kemurahan yang Rut nyatakan, latar belakang etnisnya selalu melekat kepadanya. ${ }^{40}$ Rut tidak dapat menerima penerimaan total dari penduduk Betlehem. ${ }^{41}$ Roop mengungkapkan bahwa tembok pemisah sosial tampaknya tak tertembuskan oleh Rut, karena jarang sekali ia disebut tanpa identitas etnisnya sebagai wanita Moab. ${ }^{42}$ Peter H. W. Lau menyatakan bahwa terlepas upaya terbaik Rut untuk berasimilasi ke dalam masyarakat Israel, ia tetap tak dapat lepas dari Moab sebagai asal usulnya. ${ }^{43}$ Rut mempunyai identitas "hibrid", ia bukanlah Moab ataupun Israel, tetapi mempunyai kedua elemen tersebut. ${ }^{44}$ Andrew J. Niggemann menyatakan bahwa "Ruth cannot be considered a bona fide Israelite, she remained a partial foreigner even after her marriage to Boaz."45 Status legal Rut paling maksimal dalam konteks Israel adalah גֵ $(g \bar{e} r) .{ }^{46}$ Posisi Rut terletak antar batas antara orang Israel dan non-Israel. ${ }^{47}$

Hal ini menunjukkan betapa tidak mudahnya orang asing masuk dan menjadi bagian dari kelompok lain, sehingga "keasingannya" itu terhapuskan. Dalam ungkapan lainnya "sekali orang asing, tetap orang asing”.

\section{Dua Sisi Kehidupan sebagai Orang Asing}

Kitab Rut memberikan dua sisi kehidupan sebagai orang asing. Sisi kegagalan dan sisi kesuksesan. Kehidupan keluarga Elimelekh sebagai orang asing di Moab mengisahkan kisah sedih dan kehilangan total. Keluarga Elimelekh yang meninggalkan tanah

\footnotetext{
${ }^{40}$ Jones III, Reading Ruth in the Restoration Period, 21.

${ }^{41}$ Jones III, Reading Ruth in the Restoration Period, 54.

${ }^{42}$ Roop, Ruth, Jonah, Esther, 17.

${ }^{43}$ Lau, "Another Postcolonial Reading of the Book of Ruth", 24-25.

${ }^{44}$ Lau, "Another Postcolonial Reading of the Book of Ruth", 25.

45 Niggemann, "Matriarch of Israel or Misnomer?", 357.

${ }^{46}$ Niggemann, "Matriarch of Israel or Misnomer?", 376.

${ }^{47}$ Niggemann, "Matriarch of Israel or Misnomer?”, 377.
} 
airnya untuk pergi ke tanah Moab demi menghindarkan dari bencana kelaparan, berakhir dengan kematian seluruh laki-laki dari keluarganya. Mereka berpindah untuk menghindari kelaparan, tetapi pada akhirnya mengalami kematian. Kisah semacam ini tidaklah asing di antara para pendatang dan orang asing yang berupaya mencari kehidupan yang lebih baik di tempat atau negara lain.

Di sisi lain kitab Rut juga mengisahkan kisah "sukses" Rut yang berani meninggalkan Moab dan mengikuti mertuanya dan hidup sebagai orang asing di Betlehem-Yehuda. Walau kehidupan Rut dihargai dan dipuji oleh pelbagai pihak dan bahkan ia dicatat sebagai bagian dari silsilah raja Israel yang terbesar, yaitu Daud, namun status "asing" itu selalu menempel dalam dirinya. Tekad dan harapan untuk mewujudkan "Bangsamulah bangsaku dan Allahmulah Allahku" tidaklah dapat tercapai secara total. Walau ia telah "terserap" begitu rupa dalam kehidupan bangsa Israel, ia tetap menjadi "asing" bagi bangsa Israel. Ini realita kehidupan pendatang atau orang asing. Di sisi lain Rut dijadikan tokoh utama dalam kitab Suci dan merupakan suatu sindiran bagi kehidupan bangsa Israel yang dianggap jauh dari Allah pada masa Hakim-hakim (latar belakang historis kitab ini) atau pun dalam konteks penyusunan kitab ini pada masa pasca Pembuangan. Ada seorang perempuan Moab yang hidup setia kepada Allah dan sesamanya di tengah ketidaksetiaan bangsa Israel sebagai umat Allah. Secara umum perempuan asing dalam Perjanjian Lama mempunyai konotasi negatif, tetapi berbeda dengan Rut, seorang perempuan Moab yang menjadi teladan kesetiaan kepada Allah dan sesama. ${ }^{48}$ Jones III mengungkapkan bahwa Rut merupakan contoh positif bagi sejarah leluhur Israel di tengah komunitas Betlehem yang menjadi contoh negatif dalam sejarah Israel. ${ }^{49}$ Rut yang merupakan

\footnotetext{
48 Siquans, "Foreignness and Poverty in the Book of Ruth", 449.

49 Jones III, Reading Ruth in the Restoration Period, 9-10.
} 
orang "kafir" (Gentiles) justru hadir sebagai Israel yang sejati dan menunjukkan bahwa orang luar (the outsiders) dapat menghadirkan manfaat yang potensial bagi komunitas Israel. ${ }^{50}$

Hal seperti ini dapat dikatakan sebagai suatu kesuksesan bagi seorang pendatang atau orang asing. Walau tetap dianggap "asing", namum kehidupannya mempunyai manfaat positif bagi masyarakat di mana ia berada. Kisah sukses seperti ini juga dapat ditemukan dalam kehidupan para pendatang atau orang asing yang berpindah ke suatu tempat atau negara lain.

\section{Aplikasi bagi Kehidupan Etnis Tionghoa di Indonesia}

Pasca kerusuhan dan Reformasi 1998 etnis Tionghoa mengalami suatu kondisi yang tidak pernah didapatkan sebelumnya. Etnis Tionghoa sekarang diakui dan ditempatkan sebagai salah satu suku Indonesia, sehingga kelompok ini dapat mempertahankan budaya, tradisi dan bahasanya. ${ }^{51}$ Semakin banyak juga etnis Tionghoa yang terjun dalam dunia politik dan pemerintahan, yang paling fenomenal adalah Ahok (Basuki Tjahaja Purnama). ${ }^{52}$ Walaupun geliat karir politik Ahok memang fenomenal, bahkan pernah diproyeksikan sebagai calon wakil presiden untuk mendampingi presiden Jokowi, namun akhirnya terganjal oleh karena kasus penistaan agama yang menyebabkannya harus dipenjarakan selama 2 tahun.

Terganjalnya karir politis Ahok tidak terlepas dari sikap dan tutur katanya yang "blak-blakan" ("kasar"). ${ }^{53}$ Banyak orang yang

\footnotetext{
50 Jones III, Reading Ruth in the Restoration Period, 10.

${ }^{51}$ Sia, Ketika Semakin Terbuka, 26.

${ }^{52}$ Sia, Ketika Semakin Terbuka, 27-29.

${ }^{53}$ Bdk. Rita Kunrat, "Lidah dan Tangan Ahok Membangunkan Macan

Tidur"dalam Ahok untuk Indonesia (Jakarta: Percetakan PT Gramedia, 2014), 159-63.
} 
mengingatkan akan hal ini, khususnya mengingat latar belakangnya sebagai etnis Tionghoa, tetapi Ahok tetap berkeyakinan bahwa itu gayanya dan sebagai etnis Tionghoa tidak perlu takut-takut lagi dalam era sekarang di Indonesia. Walau isu ketionghoaan tidak langsung dikenakan kepada Ahok, namun terganjalnya Ahok tidak dapat lepas dari unsur ini juga. Bagi penulis, walau isu sentimen agama lebih ditonjolkan, namun isu etnis juga tidak dapat dihapuskan dari kasus Ahok. Permintaan Ahok minta agar ia dipanggil sebagai BTP (Basuki Tjahaja Purnama) pasca keluar dari penjara merupakan sesuatu yang menarik. Bagi penulis beliau ingin lebih menekankan ke-Indonesia-annya daripada ke-Tionghoaannya. Komentar-komentar yang diberikan oleh BTP saat ini lebih tidak "kasar". Suatu upaya dan pendekatan yang lebih bijak dalam konteks di Indonesia.

Kitab Rut mengungkapkan bahwa proses asimilasi atau integrasi kaum pendatang atau orang asing bukanlah sesuatu yang mudah. Walau kehidupan Rut dihargai dan dipuji oleh pelbagai pihak dan bahkan ia dicatat sebagai bagian dari silsilah raja Israel yang terbesar, yaitu Daud, namun status "asing" itu selalu menempel dalam dirinya. Kitab ini dapat memberikan pelajaran penting bagi etnis Tionghoa di Indonesia.

Kisah Rut di tanah Yehuda tidak dapat disamakan dan mempunyai perbedaan dengan kisah keberadaan etnis Tionghoa di Indonesia saat ini. Rut tidak akan pernah menjadi status "saudara" dalam kehidupan bangsa Israel, sedangkan etnis Tionghoa di Indonesia saat ini adalah bagian dari bangsa Indonesia. Namun etnis Tionghoa di Indonesia tetap harus menyadari bahwa dapat saja terjadi perbedaan antara de jure dan de facto dalam penerimaan keberadaan etnis Tionghoa di Indonesia $^{54}$ Etnis Tionghoa di Indonesia tidak perlu dibayang-bayangi ketakutan

${ }^{54}$ Sia, Ketika Semakin Terbuka, 22-29. 
pengalaman masa lalu, tetapi perlu tetap ingat bahwa proses terwujudnya kesamaan total antara de jure dan de facto masih dibutuhkan waktu. Kitab Rut ini mengajarkan beberapa sikap penting, yaitu proaktif untuk mengetahui budaya dan tradisi lokal, kerja keras dan sikap merendahkan diri. Status Rut memang tetap asing, tetapi karakter yang agung dan perannya tercatat dalam kitab Suci bangsa Israel. Penulis berharap bahwa keberadaan etnis Tionghoa di Indonesia lebih berperan dan karakternya dapat menjadi contoh bagi kehidupan di Indonesia, sehingga terwujud kesamaan total antara de jure dan de facto penerimaan etnis Tionghoa sebagai bagian bangsa Indonesia.

Dalam sepanjang sejarah manusia pengalaman hidup sebagai orang asing merupakan sesuatu yang kompleks. Kitab Rut mengungkapkan dinamika kehidupan itu. Pengalaman hidup sebagai orang asing pada masa kini di pelbagai tempat masih mengkisahkan kompleksitas problematika ini. Proses dari hidup sebagai orang asing dan menjadi bagian komunitas dari suatu negara merupakan suatu perjalanan yang panjang.

\section{DAFTAR RUJUKAN}

Berman, Joshua A. "Ancient Hermeneutics and the Legal Structureof the book of Ruth" in Zeitschrift für die alltestamentliche Wissenschaft, 119, no 1, 2007: 22-38.

Carroll R., M. Daniel. "Once a Stranger, Always a Stranger? Immigration, Assimilation, and the Book of Ruth", in International Bulletin of Missionary Research, Vol. 39, No. 4, Oktober 2015: 185-8. 
Embry, Brad. "Legalities in the Book of Ruth: A Renewed Look", in Journal for the Study of the Old Testament, Vol. 41.1 (2016): 31-44.

Embry, Brad. "Redemption-Acquisition": The Marriage of Ruth as a Theological Commentary on Yahweh and Yahweh's People", in Journal of Theological Interpretation, 7.2 (2013): 257-72.

Havea, Jione and Peter H. W. Lau. Reading Ruth in Asia. Atlanta: SBL Press. 2015.

Hoffmeier, James K. The Immigration Crisis. Immigrants, Aliens, and the Bible. Wheaton: Crossway Books. 2009.

Holmstedt, Robert D. Ruth. A Handbook on The Hebrew Text. Waco, Texas: Baylor University Press. 2010.

Kunrat, Rita. "Lidah dan Tangan Akok Membangunkan Macan Tidur," Ahok untuk Indonesia. Jakarta: Percetakan PT Gramedia, 2014.

Lau, Peter H. W. "Another Postcolonial Reading of the Book of Ruth", in Reading Ruth in Asia. Atlanta: SBL Press, 2015.

Niggemann, Andrew J. "Matriarch of Israel or Misnomer? Israelite Self-Identification in Ancient Israelite Law Code and the Implications for Ruth", in Journal for the Study of the Old Testament, Vol. 41.3 (2017): 355-77.

Rees, Anthony. "The Boaz Solution: Reading Ruth in Light of Australian Asylum Seeker Discourse", in Reading Ruth in Asia. Atlanta: SBL Press, 2015.

Roop, Eugene F. Ruth, Jonah, Esther. Believers Church Bible Commentary. Scotdale: Herald Press, 2002. 
Sia, Kok Sin. Keasingan Israel dan Non-Israel dalam Kitab Ulangan serta Etnis Tionghoa di Indonesia, Disertasi, The South East Asia Graduate School of Theology (SEAGST), Yogyakarta, 2008.

Sia, Kok Sin. Ketika Semakin Terbuka. Dinamika Keberadaan Etnis Tionghoa di Indonesia dan Implikasinya bagi Pelayanan Gereja Etnis Tionghoa, Cet. IV. Malang: Media Nusa Creative, 2015.

Sin-lung Tong. "The Key to Successful Migration? Rereading Ruth's Confession (1:16-17) Through the Lens of Bhabha's Minicry", in Reading Ruth in Asia. Atlanta: SBL Press, 2015.

Siquans, Agnethe. "Foreignness and Poverty in the Book of Ruth: A Legal Way for a Poor Foreign Woman to Be Integrated into Israel", in Journal of Biblical Literature, 128, no. 3 (2009): 444-52. 